\title{
Somatostatin in the Pancreas, Stomach and Hypothalamus of the Diabetic Chinese Hamster
}

\author{
B. Petersson, R. Elde', S. Efendić, T. Hökfelt, O. Johansson, R. Luft, E. Cerasi, and C. Hellerström \\ Department of Histology, University of Uppsala, Uppsala and Karolinska Institute, Stockholm, and the Department of Endocrinology, \\ Karolinska Hospital, Stockholm, Sweden
}

Summary. The inhibitory effects of somatostatin on the release of insulin and glucagon, as well as its localization to the $A_{1}$-cells (D-cells) of the pancreatic islets, suggest a role of this peptide in carbohydrate metabolism. In the present study we have measured the percentage islet volume, the total weight of the $A_{1}$-cells and the somatostatin concentration in the pancreas of normal and spontaneously diabetic Chinese hamsters. In addition, the concentration of somatostatin in the stomach and hypothalamus as well as the insulin and glucagon content of the pancreas were evaluated. The percentage islet volume in the normal hamsters was $0.66 \pm$ 0.12 , which was in marked excess of that in the diabetic group, $0.38 \pm 0.04$. Similarly, the total weight of the $\mathrm{A}_{1}$-cells in the controls, $0.17 \pm$ $0.02 \mathrm{mg}$, was significantly larger than that in the diabetic animals, $0.12 \pm 0.02 \mathrm{mg}$. In agreement with these findings there was also a decreased pancreatic concentration of insulin and somatostatin, whereas the glucagon concentration was in the normal range. Also the stomach of the diabetic hamsters showed a decreased concentration of somatostatin. In the hypothalamus the total content of somatostatin appeared similar in the two groups of animals, but when expressed per $\mathrm{mg}$ wet weight this value was also decreased in the diabetic hamsters. These observations strongly suggest that, in the diabetic Chinese hamster, apart from the well-known B-cell deficiency there exists also a decreased functional activity of the somatostatin-producing cells.

Key words: Somatostatin, diabetic Chinese hamsters, islet cells, $A_{1}$-cells, glucagon, insulin, hypothalamus, stomach.

\footnotetext{
1 Present address: Department of Anatomy, University of Minnesota, Minneapolis, MN 55455, USA
}

The surprising finding of somatostatin or a somatostatin-like compound in a variety of extra-hypothalamic cells suggested a much broader biological significance for this peptide than was previously envisaged $[1,2,3,4,5]$. These observations were in keeping with a number of other reports indicating that somatostatin is able to suppress not only the secretion of growth hormone and TSH, but also of several other hormones, such as insulin, glucagon and gastrin $[6,7,8]$. Although the precise pathophysiological role of somatostatin is thus far ill-defined, its potent inhibitory effects on insulin and glucagon release suggest that it might have a glucoregulatory function.

A legitimate question is whether somatostatin participates in the establishment or maintenance of the diabetic syndrome: Recent studies $[9,10]$ have demonstrated that the pancreatic content of somatostatin is increased in streptozotocin-induced diabetes in the rat. However, since this form of diabetes is hardly representative of genetic diabetes mellitus, the role of pancreatic somatostatin in the genesis of this disease remains obscure. It is also not known whether somatostatin occurring in the hypothalamus and stomach is of any aetiological significance in this context. In the present report we attempt to elucidate these questions by studying the volume of the pancreatic $\mathrm{A}_{1}$-cells and the somatostatin content of the pancreas in Chinese hamsters with hereditary diabetes. Apart from the pancreas, somatostatin was also measured in the stomach and hypothalamus.

\section{Materials and Methods}

\section{Preparation of Tissue}

Nine diabetic, non-ketotic Chinese hamsters (Cricetulus griseus), $12-16$ months old, as well as five 
age- and weight-matched non-diabetic controls were kindly provided by Dr K. Schultz (Thomae GmbH, Biberach an der Riss, W. Germany). After arrival in the laboratory the animals had free access to a uniform diet. A week later, blood was collected from the orbital vein during light ether anaesthesia, and the blood glucose concentration determined according to Hjelm and de Verdier [11]. Immediately after blood sampling the animals were killed by decapitation. The pancreas was rapidly dissected out, weighed and subdivided into three pieces. One piece from the body and one from the head were immersed in Zenker-formalin solution, dehydrated and embedded in paraffin wax. The remaining pancreatic tissue was quickly weighed and frozen in liquid nitrogen. The hypothalamus and the lower part of the stomach including the pylorus were quickly dissected, weighed and frozen in liquid nitrogen.

\section{Quantitative Histology of the Islets}

The paraffin embedded pancreatic tissue was cut into $4 \mu$ thick sections which were either silver impregnated [12] or granule stained with Gomori's chrome-haematoxylin ponceau fuchsin [13]. The percentage volume of islet tissue was evaluated in the light microscope at a magnification of $125 \times$ according to the point sampling technique of Chalkley [14]. For this purpose, a square ruled grid with 121 intersection points was placed in the focal plane of the microscope eye-piece, and the number of intersections (hits) superimposed on pancreatic islets or connective tissue or vessels were counted in the stained sections. In each animal at least 30000 hits in 8 sections from both tail and head were used to compute the relative volume of islet tissue.

The percentage volume of the $\mathrm{A}_{1}$-cells was determined by point sampling [14] in silver impregnated pancreatic sections at a magnification of $1000 \times$. In each animal, at least 1000 hits superimposed on blackened $A_{1}$-cells from a minimum of 40 islets were counted. The total weight of the $A_{1}$-cells could then be calculated from their relative volume, the percentage contribution of islets and the total weight of the pancreas.

\section{Extraction of Tissues and Hormone Assay}

The frozen pieces of pancreas, stomach and hypothalamus were sonicated in approximately 20 volumes of cold acid-ethanol $[0.18$ molar $\mathrm{HCl}$ in $75 \%(\mathrm{v} / \mathrm{v})$ ethanol] and extracted for $16-18$ hours at $4^{\circ} \mathrm{C}$. After centrifugation at $2000 \mathrm{~g}$ for $20 \mathrm{~min}$ at $4^{\circ} \mathrm{C}$, the supernatants were removed and stored at $-20^{\circ} \mathrm{C}$ until assayed.
Acid ethanol extracts were diluted with the buffer used in each of the radioimmunoassays. Somatostatin was measured with the radioimmunoassay of Elde et al. (submitted for publication), which uses a guinea pig anti-somatostatin antibody, cyclic somatostatin standards (number 84-60, kindly provided by Dr R. Guillemin), and Tyr ${ }^{1}$-somatostatin (number DC-3-79, kindly provided by $\mathrm{Dr} A$. Arimura) which was labelled by the lactoperoxidase method [15] and purified by ion exchange chromatography on carboxymethyl cellulose [16]. Free ${ }^{125}$ I-Tyr $^{1}$-somatostatin was absorbed onto charcoal-coated dextran [17] and counted in a Packard gamma counter.

Insulin was assayed using a rabbit anti-bovine/ porcine insulin antibody, rat insulin standards (kindly provided by Dr J. Schlichtkrull, Novo Research Laboratories, Copenhagen, Denmark) and ${ }^{125}$ I-insulin (Amersham). Free ${ }^{125}$ I-insulin was absorbed onto charcoal-coated dextran [17] and counted.

Glucagon was assayed using antiserum $30 \mathrm{~K}$ (Dr R. Unger), glucagon standards and ${ }^{125} \mathrm{I}$-glucagon, labelled and purified as for somatostatin. Separation of antibody bound and free labelled glucagon was accomplished with charcoal-coated dextran as above.

\section{Results}

The blood glucose concentration was $124 \pm$ $7 \mathrm{mg} / 100 \mathrm{ml}$ in the controls and $410 \pm$ $32 \mathrm{mg} / 100 \mathrm{ml}$ in the diabetic animals $(\mathrm{p}<0.001)$. Qualitative studies of the pancreatic sections suggested that islets were less numerous in the pancreas of the diabetic hamsters. It was also found that signs of degeneration, such as cells exhibiting vacuoles, possibly corresponding to so called ballooning degeneration, were occasionally present in the islets of these animals. These cells presumeably represented B-cells since they were localized in the central parts of the islets.

The total pancreatic weight in the control group was $243 \pm 11 \mathrm{mg}$ wet weight and in the diabetic group $261 \pm 15 \mathrm{mg}(\mathrm{p}>0.05)$. The percentage islet volume in the former group was $0.66 \pm 0.12$, which was in significant excess of that in the diabetic group, $0.38 \pm 0.04(\mathrm{p}<0.05)$. The percentage contribution of $\mathrm{A}_{1}$-cells to the islet parenchyma was similar and amounted to $11.5 \pm 1.3 \%$ in the control animals and $11.9 \pm 1.3 \%$ in the diabetic animals. However, calculations of the total weight of the $A_{1}$ cells showed that the weight in the controls, $0.17 \pm$ $0.02 \mathrm{mg}$, was significantly larger than that in the diabetic hamsters $(0.12 \pm 0.02 \mathrm{mg} ; \mathrm{p}<0.05)$. 
The hormone concentrations in the pancreas are presented in Table 1. There was, firstly, a much smaller insulin concentration in the pancreas from the diabetic hamsters than in that from the normal ones and, secondly, the concentration of somatostatin was significantly decreased in the pancreas of the diabetic group. In contrast, the glucagon concentration showed a slight though not significant increase. As can be seen in Table 2, there was a marked decrease also in the somatostatin concentration of the stomach in the diabetic hamsters. The hypothalamic store of somatostatin was similar in the two animal groups when calculated per total hypothalamic weight. However, careful dissections using identical landmarks for hypothalamic pieces in the two groups, indicated a higher total hypothalamic wet weight in the diabetic, $58.5 \pm 1.6 \mathrm{mg}$, than in the normal animal group, $49.1 \pm 3.0 \mathrm{mg}$. When calculated per mg wet weight the hypothalamic somatostatin concentration of the diabetic animals, $598 \pm$ $28 \mathrm{pg} / \mathrm{mg}$ wet weight was, therefore, lower than that in the normal group, $708 \pm 34 \mathrm{pg} / \mathrm{mg}$ wet weight $(\mathrm{p}<0.05)$.

\section{Discussion}

Previous light microscopic studies of the islets in hereditary diabetic hamsters have shown glycogen infiltration of the B-cells and a deficient proliferation and decreased total volume of these cells [18, $19,20]$. Electron microscopy has furthermore revealed a marked degranulation of the B-cells, some of which showed signs of cytoplasmic degeneration and necrosis $[20,21]$. By contrast, the islet $A_{2}$-cells of the diabetic hamster have been found to be well granulated and without morphological signs of degeneration [22]. In fact, an increased pancreatic concentration of glucagon and an enhanced response to arginine has been reported by Grodsky et al [23]. The present observations of a decreased total islet volume, a pronounced depletion of pancreatic insulin and a slightly elevated glucagon concentration of the diabetic hamster pancreas agree well with these observations. The presence of vacuolated islet cells also suggests the occurrence of soluble glycogen in these cells. These findings, together with the pronounced hyperglycaemia, leave no doubt that the diabetic syndrome of the present animals was associated with severe insufficiency of the B-cells.

Unlike the findings-in the B-cells, previous electron microscopic studies have failed to demonstrate morphological changes of the islet $\mathrm{A}_{1}$-cells (D-cells) in the diabetic hamster pancreas [20]. Our data, however, indicate a decreased total mass of these cells associated with a diminished concentration of
Table 1. Concentrations of insulin, glucagon and somatostatin in the pancreas of normal and hereditary diabetic hamsters

\begin{tabular}{llll}
\hline Animals & $\begin{array}{l}\text { Insulin } \\
\mu U / m g\end{array}$ & $\begin{array}{l}\text { Glucagon } \\
\text { ng/mg wet wt }\end{array}$ & $\begin{array}{l}\text { Somatostatin } \\
\mathrm{pg} / \mathrm{mg} \text { wet wt }\end{array}$ \\
\hline Controls $(\mathrm{n}=5) 672 \pm 82$ & $2.63 \pm 0.33$ & $202 \pm 18$ \\
Diabetics $(\mathrm{n}=9) 160 \pm 25^{\mathrm{c}}$ & $3.44 \pm 0.34^{\mathrm{a}}$ & $155 \pm 12^{\mathrm{b}}$ \\
\hline $\mathrm{a}$ & $\mathrm{p}>0.05$ vs. controls & \\
b $\mathrm{p}<0.05$ vs. controls & & \\
c $\mathrm{p}<0.001$ vs. controls & &
\end{tabular}

Table 2. Occurrence of somatostatin in the stomach and hypothalamus of normal and hereditary diabetic hamsters

\begin{tabular}{lcl}
\hline Animals & $\begin{array}{l}\text { Stomach } \\
\text { pg/mg wet wt }\end{array}$ & $\begin{array}{l}\text { Hypothalamus } \\
\text { pg per total organ }\end{array}$ \\
\hline Controls $(\mathrm{n}=5)$ & $1001 \pm 160$ & $35.1 \pm 3.6$ \\
Diabetics $(\mathrm{n}=9)$ & $400 \pm 24^{\mathrm{b}}$ & $35.1 \pm 1.3^{\mathrm{a}}$ \\
\hline
\end{tabular}

a $p>0.05$ vs. controls

b $\mathrm{p}<0.001$ vs. controls

pancreatic somatostatin. It is of considerable interest in this context that Orci et al [9] recently demonstrated a significantly increased total volume of immunofluorescent somatostatin containing islet cells in streptozotocin diabetic rats. These observations were confirmed by others who found a striking increase in immunoreactive somatostatin concentration of islets isolated from rats [10] and in whole pancreas from mice (Elde et al, to be published) rendered diabetic with streptozotocin. These findings are in line with earlier ones in alloxan diabetic rats showing an increased total weight of the $A_{1}$ cells [24]. Altogether these observations indicate that, in the experimental type of diabetes, the somatostatin producing islet cells exhibit a proliferative and hyperactive response, whereas there is a regressive change of these cells in the hereditary diabetic hamsters. It is worthy of note that these quite different reactions of the $A_{1}$-cells occurred in diabetic syndromes which are both characterized by severe insulin deficiency. Thus, the regressive changes of the $\mathrm{A}_{1}$-cells in the diabetic Chinese hamster are probably not a secondary consequence of the insulinopenia, and might possibly constitute one genetic marker of the disease. However, our data do not exclude the possibility that these changes are secondary to the metabolic derangement in this species.

The present observation in the diabetic Chinese hamsters of a marked decrease in somatostatin concentration in the pyloric antrum also is of considerable interest. This tissue has previously been found to contain a substantial concentration of somatostatin and also abundant cells reacting with antisomatostatin antibodies $[3,5,25]$. Although the 
precise relationship between the somatostatin containing cells in the pancreas and those in the stomach is obscure, their similar alterations in the diabetic hamster favour the idea that these cells may in some way be functionally interrelated. The recent discovery that not only somatostatin but also gastrin may be stored in the human $A_{1}$-cell [26], and that pancreatic-type glucagon may be produced also by endocrine cells in the stomach wall [27], is further evidence for the close interrelationship between the endocrine systems in the gut and the pancreas. To what extent these two somatostatin producing cell systems are related to that in the hypothalamus remains to be evaluated. The present failure to demonstrate any marked changes in the hypothalamic somatostatin content does not exclude the existence of such a relationship.

Acknowledgements. The skilled technical assistance of Anna-Britta Andersson, Astrid Nordin, Kerstin Willander, Marianne Kjellberg, Inga Larsson and Arwed Roovete is gratefully acknowledged. Financial aid was generously given by the Swedish Medical Research Council, the American Diabetes Association, Minnesota Affiliate, Magnus Bergvall's Foundation, and a National Institutes of Health National Research Service Award to R. E. (NS 0547-01).

\section{References}

1. Luft, R., Efendić, S., Hökfelt, T., Johansson, O., Arimura, A.: Immunohistochemical evidence for the localization of somatostatin-like immunoreactivity in a cell population of the pancreatic islets. Med. Biol. 52, 428-430 (1974)

2. Polak, J.M., Pearse, A. G.E., Grimelius, L., Bloom, S. R., Arimura, A.: Growth-hormone release-inhibiting hormone in gastrointestinal and pancreatic D-cells. Lancet 1975 I, $1220-1222$

3. Hökfelt, T., Efendić, S., Hellerström, C., Johansson, O., Luft, R., Arimura, A.: Cellular localization of somatostatin in endocrine-like cells and neurons of the rat with special references to the $A_{1}$-cells of the pancreatic islets and to the hypothalamus. Acta Endocrinol. [Suppl.] 200 (Kbh.) 80, $1-41(1975)$

4. Dubois, M.P.: Immunoreactive somatostatin is present in discrete cells of the endocrine pancreas. Proc. Natl. Acad. Sci. USA 72, 1340-1343 (1975)

5. Rufener, C., Dubois, M.P., Malaisse-Lagae, F., Orci, L.: Immunofluorescent reactivity to anti-somatostatin in the gastrointestinal mucosa of the dog. Diabetologia 11, 321-324 (1975)

6. Efendić, S., Luft, R., Grill, V.: Effect of somatostatin on glucose induced insulin release in isolated perfused rat pancreas and isolated rat pancreatic islets. FEBS Lett. 42, 169-172 (1974)

7. Sakurai, H., Dobbs, R., Unger, H.: Somatostatin-induced changes in insulin and glucagon secretion in normal and diabetic dogs. J. Clin. Invest. 54, 1396-1402 (1974)

8. Bloom, S. R., Mortimer, C. H., Thorner, M. D., Besser, G. M., Hall, R., Gomez-Pan, A., Roy, V.M., Russel, R. C. G., Coy, D.H., Kastin, A.J., Schally, A.V.: Inhibition of gastrin and gastric-acid secretion by growth hormone release-inhibiting hormone. Lancet 1974 II, 1106-1109

9. Orci, L., Baetens, D., Rufener, C., Amherdt, M., Ravazzola, M., Studrer, P., Malaisse-Lagae, F., Unger, R.: Réactivité de la cellule à somatostatine de l'ilot de Langerhans dans le diabète expérimental. C. R. Acad. Sci. [D.] (Paris) 281, 1883-1885 (1975)

10. Patel, Y.C., Weir, G.C.: Increased somatostatin content of islets from streptozotocin-diabetic rats. Clin. Endocrinol. 5, 191-194 (1976)

11. Hjelm, M., de Verdier, C.H.: A methodological study of the enzymatic determination of glucose in blood. Scand. J. Clin. Lab. Invest. 15, 415-428 (1963)

12. Hellerström, C., Hellman, B.: Some aspects of silver impregnation of the islets of Langerhans in the rat. Acta Endocrinol. (Kbh.) 35, 518-532 (1960)

13. Bencosme, S. A.: Studies on the methods of staining the islet cells of the pancreas. Arch. Pathol. 53, $87-97$ (1952)

14. Chalkley, H.W.: Method for the quantitative morphologic analysis of tissues. J. Natl. Cancer Inst. 4, 47-53 (1943)

15. Thorell, J.I., Johansson, B. G.: Enzymatic iodination of polypeptides with ${ }^{125}$ I to high specific activity. Biochim. Biophys. Acta 251, 363-369 (1971)

16. Arimura, A., Sato, H., Coy, D.H., Schally, A. V.: Radioimmunoassay for GH-release inhibiting hormone. Proc. Soc. Exp. Biol. Med. 148, 784-789 (1975)

17. Herberts, V., Lau, K.S., Gottlieb, C.W., Bleicher, S. J.: Coated charcoal immunoassay of insulin. J. Clin. Endocrinol. 25, 1375-1384 (1964)

18. Carpenter, A.M., Gerritsen, G.C., Dulin, W.E., Lazarow, A.: Islet and beta cell volumes in diabetic Chinese hamsters and their non-diabetic siblings. Diabetologia 3, 92-96 (1967)

19. Carpenter, A.M., Gerritsen, G.C., Dulin, W.E., Lazarow, A.: Islet and beta cell volumes in offspring of severely diabetic (ketotic) Chinese hamsters. Diabetologia 6, 168-176 (1970)

20. Like, A. A., Gerritsen, G.C., Dulin, W.E., Geaudreau, P.: Studies in the diabetic Chinese hamster: Electron microscopy of pancreatic islets. Diabetologia 10, 509-520 (1974)

21. Luse, S. A., Caramia, F., Gerritsen, G., Dulin, W. E.: Spontaneous diabetes mellitus in the Chinese hamster: An electron microscopic study of the islets of Langerhans. Diabetologia 3, 97-108 (1967)

22. Orci, L., Stauffacher, W., Dulin, W. E., Renold, A.E., Rouiller, Ch.: Ultrastructural changes in A-cells exposed to diabetic hyperglycemia. Observations made on pancreas of Chinese hamsters. Diabetologia 6, 199-206 (1970)

23. Grodsky, G. M., Frankel, B. J., Gerich, J. E., Gerritsen, G. C.: The diabetic Chinese hamster: In vitro insulin and glucagon release; the "chemical diabetic"; and the effect of diet on ketonuria. Diabetologia 10, 521-528 (1974)

24. Hellman, B., Petersson, B.: Long-term changes of the $A_{1^{-}}$ and $\mathrm{A}_{2}$-cells in the islets of Langerhans of rats with alloxan diabetes. Endocrinology 72, 238-242 (1963)

25. Arimura, A., Sato, H., Dupont, A., Nishi, N., Shally, A. V.: Somatostatin: Abundance of immunoreactive hormone in rat stomach and pancreas. Science 189, 1007-1009 (1975)

26. Erlandsen, S. L., Hegre, O., Parsons, J.A., McEvoy, R.C., Elde, R. P.: Pancreatic islet cell hormones, distribution of cell types in the islet and evidence for the presence of somatostatin and gastrin within the D-cell. J. Histochem. Cytochem. 24, 883-897 (1976)

27. Sasaki, H., Rubalcava, B., Baetens, D., Blazquez, E., Srikant, C. B., Orci, L., Unger, R. H.: Identification of glucagon in the gastrointestinal tract. J. Clin. Invest. 56, 135-145 (1975)

Received: January 25, 1977, and in revised form: April 15, 1977

Dr. B. Petersson

Department of Histology

University of Uppsala

Box 571

S-75123 Uppsala

Sweden 